\title{
Video Article \\ Preparation of Formalin-fixed Paraffin-embedded Tissue Cores for both RNA and DNA Extraction
} \author{
Jacques Lapointe ${ }^{3}$, Paul C. Park ${ }^{1}$, John B. A. Okello ${ }^{1,2}$, David M. Berman ${ }^{1,2}$ \\ ${ }^{1}$ Department of Pathology \& Molecular Medicine, Queen's University \\ ${ }^{2}$ Division of Cancer Biology \& Genetics, Queen's Cancer Research Institute, Queen's University \\ ${ }^{3}$ Department of Surgery, Division of Urology, McGill University \\ ${ }^{4}$ Transformative Pathology Program, Ontario Institute for Cancer Research (OICR)
}

Palak G. Patel ${ }^{1,2}$, Shamini Selvarajah ${ }^{1,2}$, Suzanne Boursalie ${ }^{1,2}$, Nathan E. How ${ }^{1,2}$, Joshua Ejdelman ${ }^{3}$, Karl-Philippe Guerard ${ }^{3}$, John M. Bartlett ${ }^{4}$,

Correspondence to: David M. Berman at bermand@queensu.ca

URL: https://www.jove.com/video/54299

DOI: doi:10.3791/54299

Keywords: Basic Protocol, Issue 114, Extraction, FFPE, Nucleic Acids (DNA and RNA), Prostate, Cancer, Deparaffinization, Archival, Pathology, Tissue, Cores

Date Published: 8/21/2016

Citation: Patel, P.G., Selvarajah, S., Boursalie, S., How, N.E., Ejdelman, J., Guerard, K.P., Bartlett, J.M., Lapointe, J., Park, P.C., Okello, J.B., Berman, D.M. Preparation of Formalin-fixed Paraffin-embedded Tissue Cores for both RNA and DNA Extraction. J. Vis. Exp. (114), e54299, doi:10.3791/54299 (2016).

\section{Abstract}

Formalin-fixed paraffin embedded tissue (FFPET) represents a valuable, well-annotated substrate for molecular investigations. The utility of FFPET in molecular analysis is complicated both by heterogeneous tissue composition and low yields when extracting nucleic acids. A literature search revealed a paucity of protocols addressing these issues, and none that showed a validated method for simultaneous extraction of RNA and DNA from regions of interest in FFPET. This method addresses both issues. Tissue specificity was achieved by mapping cancer areas of interest on microscope slides and transferring annotations onto FFPET blocks. Tissue cores were harvested from areas of interest using $0.6 \mathrm{~mm}$ microarray punches. Nucleic acid extraction was performed using a commercial FFPET extraction system, with modifications to homogenization, deparaffinization, and Proteinase $\mathrm{K}$ digestion steps to improve tissue digestion and increase nucleic acid yields. The modified protocol yields sufficient quantity and quality of nucleic acids for use in a number of downstream analyses, including a multi-analyte gene expression platform, as well as reverse transcriptase coupled real time PCR analysis of mRNA expression, and methylation-specific PCR (MSP) analysis of DNA methylation.

\section{Video Link}

The video component of this article can be found at https://www.jove.com/video/54299/

\section{Introduction}

Genomic biomarker research seeks to identify molecular correlates that accurately and reliably reflect disease status, and do so in a clinically useful manner. ${ }^{1}$ Biomarker development is reliant on retrospective analysis of well-annotated tissue samples. Diseased and normal tissue samples are stored either as fresh-frozen tissue in specialized biobanks or as formalin-fixed paraffin-embedded tissue (FFPET) blocks in clinical archives. Fresh-frozen tissue allows for the extraction of high-quality nucleic acids and has been widely used in genomic biomarker discovery studies. ${ }^{2,3}$ However, fewer tissue samples are available in biobanks and studying such tissue introduces a bias towards larger samples, unusual categories of disease, and patients seen at specialized centers with greater abilities to bank tissue. ${ }^{4}$ FFPET, in contrast, is the default storage method for diseased human and animal tissues. While FFPET blocks maintain cellular morphology, the fixation process cross-links other cellular constituents to nucleic acids. Cross-linked RNA and DNA are recoverable, but only in degraded, highly fragmented forms. ${ }^{5,6}$ However, these DNA and RNA fragments are amenable to analysis by an expanding array of assays, including mRNA expression, DNA hypermethylation, and targeted sequencing. ${ }^{7,8}$ To exploit this opportunity in the large quantity and variety of FFPET available for research, there is a need for an efficient and reliable extraction protocol.

A large proportion of biomarker research in tissue focuses on cancer. Like other types of diseased tissue, cancer tissue often shows significant regional heterogeneity in cell preservation and cell type. Since biomarker research relies on the ability to correlate constituents of diseased tissue with molecular features, a critical step of this process is the precise harvesting of tissue that is well preserved and enriched for the disease under study. In FFPET, two enrichment techniques are often utilized: laser capture microdissection (LCM), and microtome sectioning. LCM enables highly focused tissue harvesting and can be used to isolate specific, well-preserved cell types in heterogeneous tissues. 9,10 However, LCM requires expensive equipment and is prohibitively time consuming for large numbers of samples. Microtome sectioning is a more widely-used process where thin sections are cut from FFPET blocks. ${ }^{11,12}$ Microtome-cut sections often include tissue that is heterogeneous in cell preservation (e.g., necrotic vs. well-preserved) and composition (e.g., cancer vs. benign parenchyma), and hence may lead to the homogenization of molecular features best investigated separately. Thus, there is a need for a high throughput method that enriches for cells of 
interest. A third method, isolation of nucleic acids from FFPET cores, provides this enrichment, is suitable for high throughput protocols, and has been used by others to isolate RNA or DNA from separate tissue cores. ${ }^{7,13,14}$

A number of published protocols specify methods of extracting nucleic acids from FFPET (Table 1). However, protocols where RNA and DNA are extracted from the same tissue have been optimized for microtome tissue sections, but not for tissue cores. ${ }^{15,16}$ Similarly, published protocols which offer increased tissue specificity, either through tissue cores or slide microdissections, specify procedures for extraction of DNA, but not RNA. ${ }^{7,17}$ Here, an optimized protocol for dual extraction of both DNA and RNA from the same tissue core is demonstrated. Tissue cores are harvested by inserting tissue microarray (TMA) punches into regions of interest mapped onto FFPET blocks. The mapping is performed by annotating a microscope slide with a marker pen and transferring the annotation to the surface of the corresponding FFPET block (Figure 1).

Prior work that led to the development of this protocol included a comparison of several commercially available nucleic acid extraction systems. In this comparison, modifications to commercial protocols, as described below provided the highest DNA and RNA yields and quality (Selvarajah et al., In Prep). Tissue cores are thicker than the 5-10 $\mu \mathrm{m}$ micron sections typically used in FFPET extraction protocols ${ }^{11,12,14,18-20}$, and may contain more variable amounts of paraffin. To compensate for this, deparaffinization was enhanced by repeating xylene and ethanol treatments and by introducing a motorized homogenization step (Figure 1). Furthermore, proteinase K digestion times were lengthened to increase DNA yield. Overall, this protocol is cost-effective and enables the establishment of linkages between molecular and histopathologic features of disease in large, well characterized populations. The protocol in its entirety can be carried out reliably within 2 days, including $3 \mathrm{hr}$ of hands-on time, with little need for specialized or expensive equipment.

The step-by-step protocol is hereafter as a modified version of the manufacturer's protocol. ${ }^{21}$ Please see Table of Materials/Equipment for specific reagents, equipment, and manufacturers.

\section{Tissue Coring}

1. Review the microscope slide and outline the region(s) of interest using a fine-point permanent marker. Cut out a section of paraffin film large enough to cover the region of interest on the microscope slide. Place film firmly on slide and wrap film over edges to keep the film from slipping. Using a fine-point permanent marker, outline the entire tissue and the region(s) of interest within the tissue, keeping the outline touching - but outside of - the region(s).

2. Remove the film and transfer it to the corresponding tissue block. Orient the film by flipping or rotating it so that the outline of the entire tissue matches the observed shape of the tissue in the block (Figure 1). Press the section of film firmly to the surface of the block to prevent slippage.

3. Using the tip of the permanent marker, make shallow but visible $(\sim 0.2 \mathrm{~mm})$ indentations along the outline of the region(s) of interest, then remove the film. Load $1 \mathrm{ml}$ of bleach, $70 \%$ ethanol, and water into separate 1.5 or $2.0 \mathrm{ml}$ microcentrifuge tubes.

4. Clean the receptor (red) punch from the $0.6 \mathrm{~mm}$ punch set by sliding the punch up and down several times while the tip is submerged into the tube containing bleach. Repeat the above step with $70 \%$ ethanol and then water (critical to ensure that bleach is removed).

5. Press the punch into the tissue, inside the region of interest to a depth of $3 \mathrm{~mm}$ and withdraw the punch. Release the core into a low binding 1.5 or $2 \mathrm{ml}$ tube by pushing it out of the punch with the stylus. Store the cores at $-20^{\circ} \mathrm{C}$ (long-term) or $4{ }^{\circ} \mathrm{C}$ for short-term use.

6. Clean the punch according to step 1.4 and continue with the next regions or sample.

\section{Deparaffinize the FFPE Tissue Cores}

1. Carryout deparaffinization in 1.5 or $2 \mathrm{ml}$ tubes by adding $1 \mathrm{ml}$ xylene to the tissue core and vortexing vigorously for 10 sec. Heat for $3 \mathrm{~min}$ at $50^{\circ} \mathrm{C}$.

2. Centrifuge for $2 \mathrm{~min}$ at room temperature (RT) and maximum speed $(21,130 \mathrm{xg}$ ) and place tube on ice for 5 min (allows the waxy residue to solidify on the top).

3. Carefully remove paraffin accumulated around meniscus with supernatant using a pipette tip and repeat xylene treatment (steps 2.1-2.2).

4. Add $1 \mathrm{ml}$ of ethanol (100\%) and vortex vigorously for $10 \mathrm{sec}$. Centrifuge for $2 \mathrm{~min}$ at RT (maximum speed), and carefully discard the ethanol. Repeat the above step once.

\section{Homogenization of the Deparaffinized Cores}

1. Resuspend the cores in $700 \mu \mathrm{l}$ of ethanol (100\%) prior to homogenization. Using a motorized tissue homogenizer, grind the cores into fine tissue particles ( $1 \mathrm{~min}$ on medium setting). Clean the homogenizer probe between each sample to minimize carry-over contamination.

1. Fill $15 \mathrm{ml}$ tubes with $\sim 10 \mathrm{ml}$ of bleach, RNase neutralizing solution and $70 \%$ ethanol. After sample homogenization, wash the homogenizer probe in each of the cleaning solutions in the order stated above. Run the homogenizer on the highest speed during the washing stage.

2. Wipe the probe with tissue and allow probe to dry completely before homogenizing the next sample. Visually inspect the probe blades for residual tissue pieces. If found, clean the probe again. Change the cleaning solutions (bleach, ethanol, and RNase neutralizing solution) daily.

2. Following homogenization, bring the sample volume to $1 \mathrm{ml}$ by adding more $100 \%$ ethanol ( $300 \mu \mathrm{l})$. Centrifuge at maximum speed for 15 $\mathrm{min}$, carefully aspirate the ethanol and air dry pellet for approximately 15-20 min before proceeding with RNA extraction. 


\section{Digestion with Proteinase $\mathrm{K}$}

1. Resuspend the pellet in $150 \mu \mathrm{l}$ Proteinase $\mathrm{K}$ digestion Buffer and flick tube to loosen the pellet. Add $10 \mu \mathrm{l}$ of temperature-stable proteinase $\mathrm{K}$ and mix by flicking (do not vortex the tube). Incubate the content in the tube at $56^{\circ} \mathrm{C}$ for 15 min with mild agitation.

2. Allow tube to incubate on ice for $3 \mathrm{~min}$. Complete cooling is important for efficient precipitation in the following step. Centrifuge for 15 min at maximum speed.

\section{Separate RNA from DNA}

1. Carefully transfer the supernatant, without disturbing the pellet, to a new $1.5 \mathrm{ml}$ for RNA purification.

2. Keep the pellet for DNA purification (pellet can be stored for $2 \mathrm{hr}$ at $\mathrm{RT}$, for up to 1 day at $2-8{ }^{\circ} \mathrm{C}$, or for longer periods at $-20^{\circ} \mathrm{C}$ ).

\section{RNA Purification}

1. Incubate the RNA-containing supernatant at $80^{\circ} \mathrm{C}$ for $15 \mathrm{~min}$ (do not exceed this time). Next, briefly centrifuge the tube to collect drops from the inside of the lid.

2. Add $320 \mu$ l Buffer RLT to adjust binding conditions, and mix by pipetting. Next, add $720 \mu$ l ethanol (100\%), and vortex.

3. Transfer $600 \mu \mathrm{l}$ of the sample, including any precipitate that may have formed, to RNA spin column (supplied in the kit) placed in a $2 \mathrm{ml}$ collection tube and set aside the remaining content. Centrifuge for $15 \mathrm{sec}$ at $\geq 8,000 \mathrm{x}$, discard the flow-through and reuse the collection tube.

4. Transfer remaining sample onto a column, including droplets that may have accumulated in the lid of the tube, centrifuge for 15 sec at $\geq 8,000$ $\mathrm{xg}$, and discard the flow-through.

5. Add $350 \mu \mathrm{l}$ Buffer FRN to the spin column and centrifuge for $15 \mathrm{sec}$ at $\geq 8,000 \mathrm{xg}$, discard the flow-through and reuse collection tube.

6. Gently mix $10 \mu \mathrm{l}$ DNase I stock solution with $70 \mu \mathrm{l}$ Buffer RDD, add directly to the spin column membrane, and incubate at RT for 15 min.

7. Add $500 \mu \mathrm{l}$ Buffer FRN to the spin column, centrifuge for $15 \mathrm{sec}$ at $\geq 8,000 \mathrm{xg}$ and save the flow-through for use in the next step. To enhance recovery of small RNAs, place the spin column in a new $2 \mathrm{ml}$ collection tube and apply the flow-through from the previous step to the spin column.

8. Centrifuge for $15 \mathrm{sec}$ at $\geq 8,000 \mathrm{xg}$, discard the flow-through and reuse the collection tube in next step. Add $500 \mu \mathrm{l}$ Buffer RPE to the spin column and centrifuge for $15 \mathrm{sec}$ at $\geq 8,000 \mathrm{x} \mathrm{g}$, discard the flow-through and reuse the collection tube in the next step.

9. Add $500 \mu \mathrm{l} \mathrm{Buffer} \mathrm{RPE}$ to the spin column and centrifuge for $15 \mathrm{sec}$ at $\geq 8,000 \mathrm{xg}$ and discard the collection tube with the flow-through.

10. Place the spin column in a new $2 \mathrm{ml}$ collection tube, open the lid and centrifuge at maximum speed for 5 min. Discard the collection tube with the flow-through.

11. Place the spin column in a new $1.5 \mathrm{ml}$ collection, add $20 \mu \mathrm{l}$ of RNase-free water directly onto the spin column membrane, and incubate the tube for $1 \mathrm{~min}$ at RT. Centrifuge at maximum speed for 1 min to elute the RNA. Store the eluted RNA sample at $-80{ }^{\circ} \mathrm{C}$.

\section{DNA Purification}

1. Resuspend the pellet obtained during the RNA extraction by stepwise addition of $45 \mu \mathrm{l}$ of proteinase $\mathrm{K}$ buffer $(400 \mathrm{mM}$ Tris $7.5,400 \mathrm{mM}$ $\mathrm{NaCl}, 3 \mathrm{mM} \mathrm{MgCl} 2,4 \% \mathrm{SDS}$ ); $45 \mu \mathrm{l} \mathrm{H}_{2} \mathrm{O}$; and $400 \mu \mathrm{g}$ of high potency Proteinase $\mathrm{K}$.

2. Incubate the above solution at $56{ }^{\circ} \mathrm{C}$ for $24 \mathrm{hr}$ (recommended) or overnight. Performincubation at $90^{\circ} \mathrm{C}$ for $2 \mathrm{hr}$ without agitation and briefly centrifuge the microcentrifuge tube to collect drops from inside of the lid.

3. Allow the sample to cool to RT and then add $4 \mu \mathrm{l}$ RNase $A(100 \mathrm{mg} / \mathrm{ml})$. Incubate the sample for $2 \mathrm{~min}$ at RT.

4. Add $200 \mu \mathrm{l}$ Buffer AL to the sample, and mix thoroughly by vortexing. Next, add $200 \mu \mathrm{l}$ of $100 \%$ ethanol, and mix thoroughly by vortexing. Transfer the entire sample to the provided spin column, place in a $2 \mathrm{ml}$ collection tube, and centrifuge for $1 \mathrm{~min}$ at $\geq 8,000 \times \mathrm{g}$.

5. Discard the collection tube with the flow-through and place the spin column in a new $2 \mathrm{ml}$ collection tube. Add $700 \mu \mathrm{l}$ Buffer AW1 to the spin column, centrifuge for $15 \mathrm{sec}$ at $\geq 8,000 \mathrm{x} \mathrm{g}$, discard the flow-through and reuse the collection tube.

6. Add $700 \mu \mathrm{l}$ Buffer AW2 to the spin column, centrifuge for $15 \mathrm{sec}$ at $\geq 8,000 \times \mathrm{g}$, discard the flow-through and reuse the collection tube. Next, add $700 \mu \mathrm{l}$ of $100 \%$ ethanol to the spin column, centrifuge for $15 \mathrm{sec}$ at $\geq 8,000 \times \mathrm{g}$ and discard the collection tube with the flow-through.

7. Place the spin column in a new $2 \mathrm{ml}$ collection tube, open the lid of the spin column, and centrifuge at full speed for $5 \mathrm{~min}$. Discard the collection tube with the flow-through.

8. Place the spin column in a new $1.5 \mathrm{ml}$ collection tube and add $25 \mu \mathrm{l}$ of heated nuclease-free water $\left(50{ }^{\circ} \mathrm{C}\right)$. Incubate column and tube at 50 ${ }^{\circ} \mathrm{C}$ for $10 \mathrm{~min}$. Centrifuge for $1 \mathrm{~min}$ at maximum speed, add $25 \mu \mathrm{l}$ of nuclease-free water (RT) to column and incubate for $1 \mathrm{~min}$ at RT.

9. Centrifuge for $1 \mathrm{~min}$ at maximum speed $(21,130 \times \mathrm{g})$ and harvest flow-through containing genomic DNA (approximately $50 \mu \mathrm{l}$ of DNA in total) Store the column at $-20^{\circ} \mathrm{C}$ (in case another elution is required later).

\section{Representative Results}

This protocol represents an optimized method for recovering DNA and RNA from tissue cores, using modifications of a commercial extraction system designed for tissue sections. Optimization included the introduction of tissue homogenization, utilization of more potent Proteinase $\mathrm{K}$ for DNA extraction, and extension of tissue digestion time. Graphs and statistical analyses included 2-way ANOVA, linear regression and correlation.

Optimizations of Proteinase Digestion

The commercial kit included a room temperature stable proteinase $\mathrm{K}$ solution which was substituted with a more potent proteinase $\mathrm{K}$, resulting in higher DNA yield (Figure 2A). To further increase the DNA yields, digestion was extended from 2 to 24 hr. No significant differences were seen between the two time points, but the $24 \mathrm{hr}$ digestion appeared to provide more consistent yields across samples. However, further incubation to $48 \mathrm{hr}$ did not further improve DNA recovery (Figure $2 \mathrm{~B} ; \mathrm{p}=0.74$ ). 
Typical DNA Recovery from FFPE Prostate Cancer Tissue Samples

Using the optimized protocol, RNA and DNA were co-extracted from 333 prostate cancer FFPET samples ranging from 3 to 14 years in sample age. From each sample, 3 tissue cores (average total tissue volume of $0.95 \pm 0.13 \mathrm{~mm}^{3}$ ) were used as input. While there are other microfluidic based gel-electrophoresis methods which can estimate concentrations and provide evaluations of the size distribution of nucleic acids molecules, such methods do not provide reproducible nucleic acids quantification, and cannot distinguish between RNA and DNA as flourometrically-based assays do. ${ }^{22}$ And, because microfluidic based gel-electrophoresis results are not reliable for fragmented nucleic acids derived from FFPET, ${ }^{23}$ nucleic acid yields were measured fluorometrically (see reagent list for details). The average yield was $2,270 \mathrm{ng}$ of RNA and $820 \mathrm{ng}$ of DNA (Figure 3A). Approximately $90 \%$ of all FFPET samples analysed in this study yielded $\geq 100 \mathrm{ng}$ of DNA and $\geq 500 \mathrm{ng}$ of RNA. Interestingly, there was no significant correlation between the age of the FFPET sample and nucleic acid recovery (Figure 3B). Overall, RNA and DNA yields were correlated across samples $\left(R^{2}=0.39 ; p<0.0001\right)$, although more than twice as much RNA than DNA was recovered from each sample (Figure 3C).

As the pilot and optimization work was performed on prostate tissues, the next step was to investigate the performance of this protocol on a few additional types of archival tissue. Starting with surgically removed and autopsy FFPET samples representing benign liver (1 sample from 1 case), cancers of the brain ( 8 samples from 1 case), urinary bladder ( 2 samples from 2 cases), and breast ( 3 samples from 3 cases), the protocol yielded $>100 \mathrm{ng}$ of DNA and RNA from $90 \%$ of samples (Figure 3D). While nucleic acid yields were lower in autopsy tissues than in surgical tissues, representative results indicate that the protocol produces similar yields across cancers derived from different sites.

Assessment of RNA and DNA Integrity and their Representative Performance in Downstream Analysis

RNA expression analysis of 47 genes in 8 selected FFPET prostate cancer samples and a fresh PC-3 prostate cancer cell line sample (as a positive control) was performed using a commercial multianalyte gene expression platform that is optimized for FFPET. The mRNA counts in PC3 were typically higher than those from FFPET samples (Figure 4A). However, comparing relative expression of all genes, FFPET prostate cancer samples showed similar expression profiles to PC-3 RNA, indicating that both sources of RNA are suitable for RNA expression profiling.

To demonstrate performance of genomic DNA extracted with this protocol, bisulfite-converted DNA extracts from FFPET samples were amplified by methylation specific PCR (MSP). ${ }^{24}$ MSP analysis of ALU repetitive elements, highly methylated regions present in millions of copies in the human genome ${ }^{25}$ was used as a genomic methylation control, and expected to show minimal variations between samples. As shown in Figure 4B, there was little to no variation seen between different samples in ALU MSP methylation levels. Further, MSP assays based on GSTP1, a gene known to be hypermethylated in prostate cancer but not in benign samples, ${ }^{26}$ showed no detectable amplifications in DNA from benign samples. As expected, lower qPCR cycle threshold values were detected in DNA from cancer tissues, indicating enrichment of methylated GSTP1 copies. The utility of nucleic acids recovered by this protocol was further tested in typical downstream assays, using nucleic acids recovered from benign liver and from a brain (post-mortem) and from two surgically removed breast cancer samples. Both RT-qPCR based expression and MSP assays performed well on breast cancer and liver FFPET, but the RT-PCR assay failed to amplify a highly expressed mRNA from the post-mortem brain tumor sample (Figure 4C), suggesting that RNA had degraded, likely due to delayed tissue fixation. 


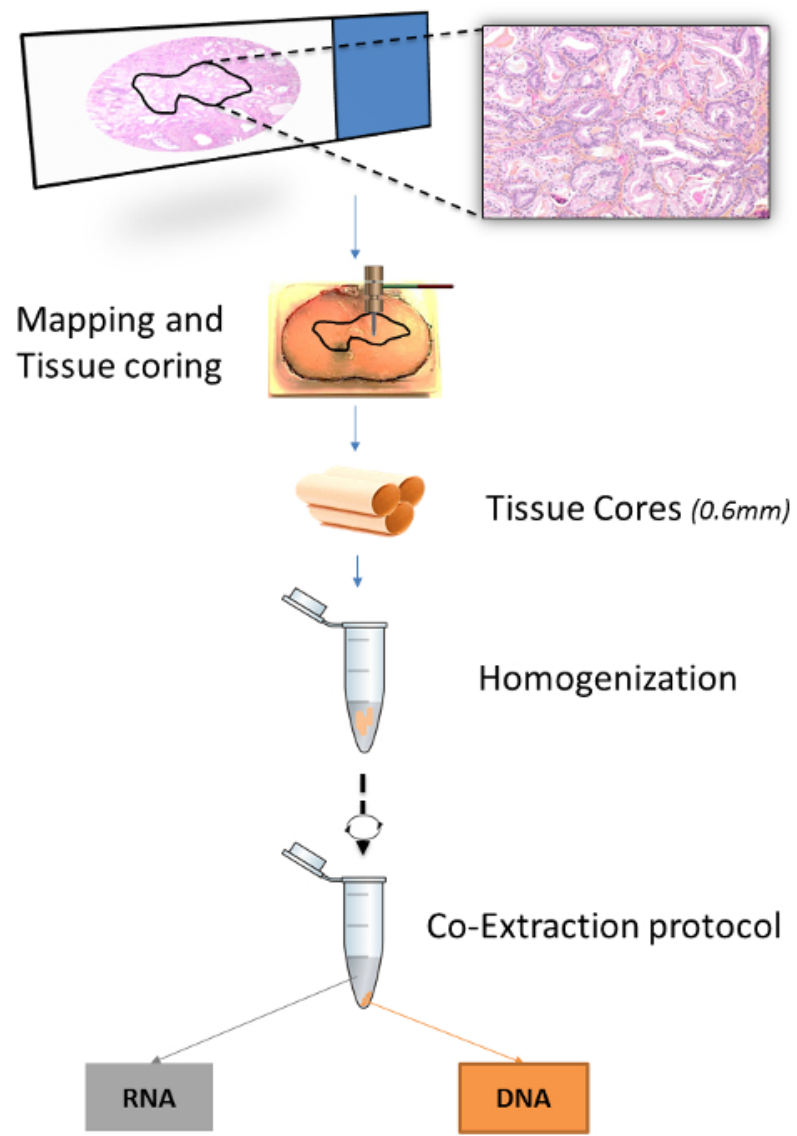

Figure 1: Overview of the Extraction Procedure for FFPET Samples. The figure illustrates how an area of interest in a tissue block is mapped based on histopathologic selection from a microscope slide. Three $0.6 \mathrm{~mm}$ tissue cores are then obtained from each tissue area by using biopsy punches, homogenized together and then subjected to extraction of both RNA and DNA. Please click here to view a larger version of this figure.

A

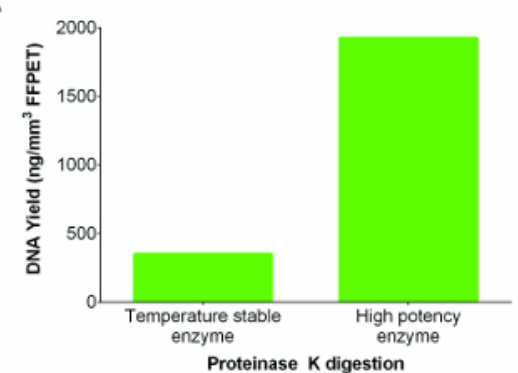

B

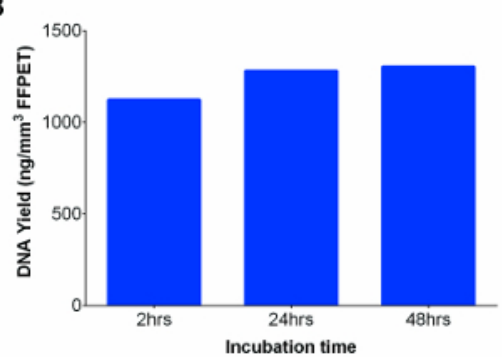

Figure 2: Nucleic Acids (DNA and RNA) yields in $\mathrm{ng} / \mathrm{mm}^{3}$ of FFPET from two Proteinase K (Temperature Stable and High Potency Enzymes), and Tested across a Range of Incubation Times for the Latter. (A) Performance of Proteinase K from different suppliers. DNA extractions were performed on a representative FFPET sample using temperature stable enzyme supplied with the kit versus a more potent enzyme from another manufacturer. (B) Determining optimum Proteinase K incubation time to maximize the DNA yield. Performance of high concentration Proteinase $\mathrm{K}$ digestion was evaluated at three different incubation periods using 3 FFPET samples. Error bars represent standard error of mean (SEM). Please click here to view a larger version of this figure. 
A

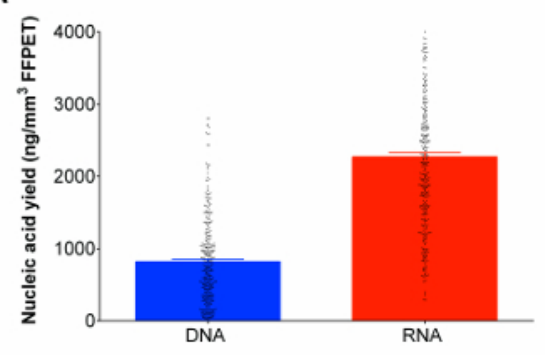

C

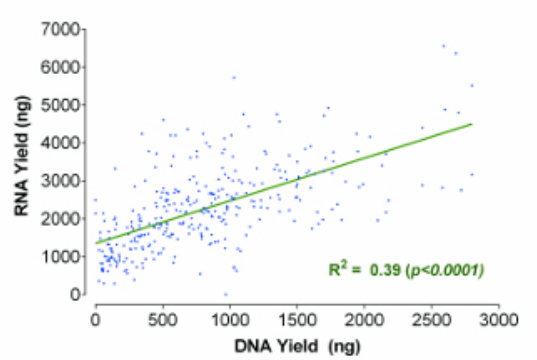

B

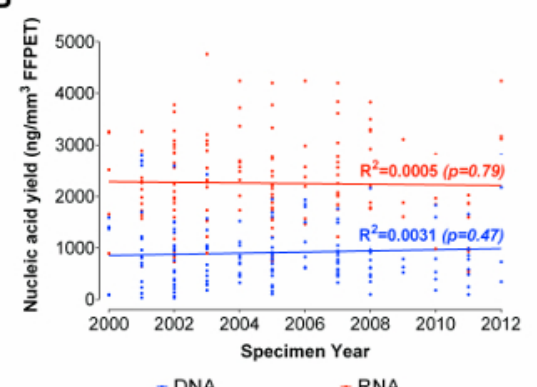

D

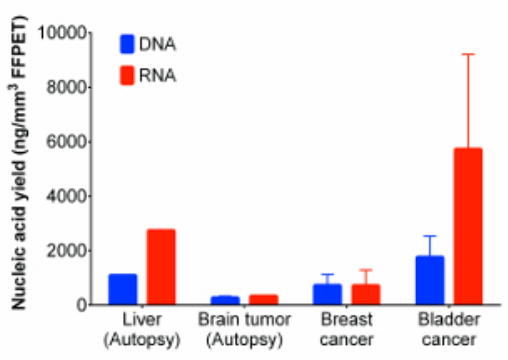

Figure 3: Nucleic Acids (DNA and RNA) yields in $\mathrm{ng} / \mathrm{mm}^{3}$ of FFPET in Total, across Sample Years and Representative Tissue Types. (A) Total recovered nucleic acids from formalin-fixed paraffin-embedded tissue. The nucleic acids quantities presented are based on the extractions of 333 FFPET samples using the optimized protocol. (B) Correlation plot between recovered total DNA and RNA and the age of FFPET samples. The extracted FFPET samples used were obtained from the years 2000 to 2012. (C) Correlation between yields from concurrently extracted DNA and RNA from 333 prostate samples. There is a positive correlation between DNA and RNA yields. (D) Demonstration of the protocol using additional archival tissue types. The optimized protocol was used to extract nucleic acids from 14 cancer (breast, bladder and brain) and normal (liver) samples. Error bars represent SEM. Please click here to view a larger version of this figure. 
A

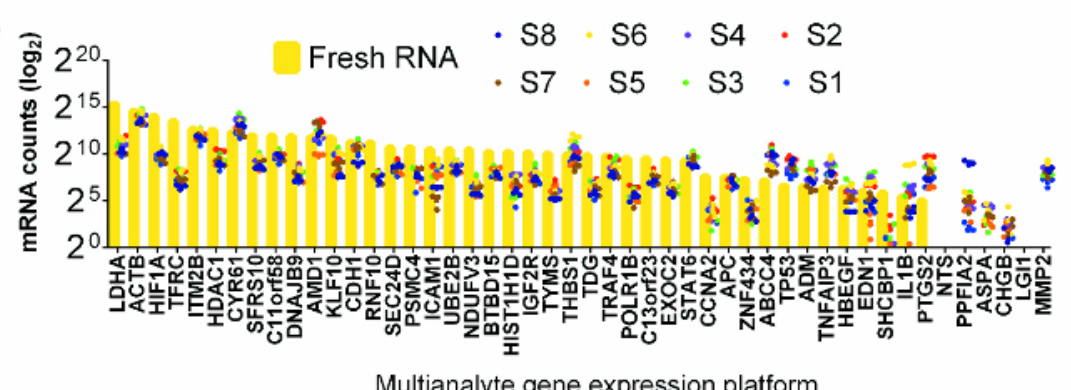

B

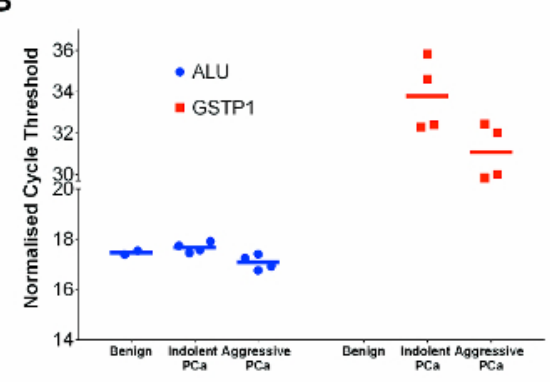

C

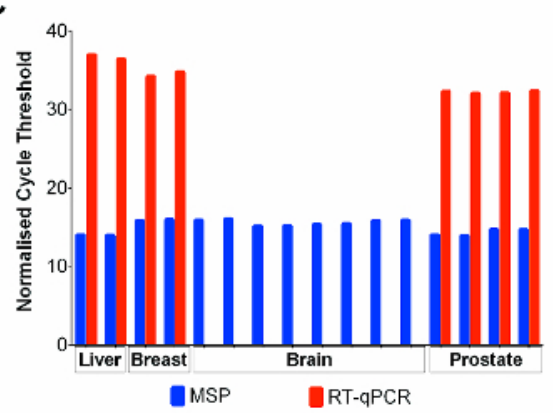

Figure 4: Performance of RNA and DNA Co-extracted from Tissue Cores in Downstream Applications. (A) mRNA counts for FFPE prostate cancer tissues and for fresh PC-3 cell line control. Each point represents the average of 3 technical replicates extracted separately. Fresh PC-3 cell line RNA values are illustrated by yellow bars and FFPET tissue values are represented by coloured dots. (B) Methylation specific PCR assays on DNA of FFPET prostate cancer samples. Cycle threshold values were obtained for 10 samples performed as expected using $50 \mathrm{ng} /$ reaction of bisulfite converted DNA. ALU MSP assays from all FFPET samples had similar cycle threshold values ( $p>0.67)$. GSTP1 MSP assays showed higher methylation (lower cycle threshold) levels in prostate cancer than in benign prostate. (C) Assessment of DNA and RNA quality from additional tissue types. HPRT1 gene expression and Alu gene methylation assays were performed on nucleic acids (RNA and DNA respectively) extracted from normal liver (autopsy), and brain (autopsy) and breast cancers (all FFPET). Results from prostate are shown for comparison. Note: similar results were observed from each tissue type, except for failed mRNA amplification from one autopsy sample. Each point or bar represents a sample, and error bars represent SEM. Please click here to view a larger version of this figure. 


\begin{tabular}{|c|c|c|c|c|c|c|c|c|c|c|c|}
\hline \multicolumn{12}{|c|}{ Tissue Cores } \\
\hline & \multirow{2}{*}{$\begin{array}{l}\text { Tissue } \\
\text { Input } \\
\text { (mm3) }\end{array}$} & \multirow{2}{*}{$\begin{array}{l}\text { Extracted } \\
\text { Nucleic } \\
\text { Acid }\end{array}$} & \multicolumn{2}{|l|}{ Validation } & \multicolumn{3}{|c|}{ Quality check: DNA } & \multicolumn{4}{|c|}{ Quality check: RNA } \\
\hline & & & $\begin{array}{l}\text { (\# of } \\
\text { samples) }\end{array}$ & $\begin{array}{l}\text { Age of } \\
\text { Sample } \\
\text { (years) }\end{array}$ & $\begin{array}{l}\text { Total Yield } \\
\text { (ng) }\end{array}$ & $\begin{array}{l}\text { Fragment } \\
\text { size (bp) }\end{array}$ & PCR & $\begin{array}{l}\text { Total Yield } \\
\text { (ng) }\end{array}$ & $\begin{array}{l}\text { Fragment } \\
\text { size (bp) }\end{array}$ & PCR & NanoString \\
\hline $\begin{array}{l}\text { Pikor et } \\
\text { al. }\end{array}$ & $43-129$ & DNA & No data & No data & No data & No data & & & & & \\
\hline $\begin{array}{l}\text { Montaser- } \\
\text { Kouhsari } \\
\text { et al. }\end{array}$ & $18-29.5$ & RNA & 763 & $0-25$ & & & & 843 & No data & & \\
\hline This paper & 1.71 & $\begin{array}{l}\text { DNA and } \\
\text { RNA }\end{array}$ & $>350$ & $3-12$ & 820 & $100-500$ & $\checkmark$ & 2270 & $100-500$ & $\checkmark$ & $\checkmark$ \\
\hline \multicolumn{12}{|c|}{ Tissue Sections } \\
\hline & \multirow{2}{*}{$\begin{array}{l}\text { Tissue } \\
\text { Input }\end{array}$} & \multirow{2}{*}{$\begin{array}{l}\text { Extracted } \\
\text { Nucleic } \\
\text { Acid }\end{array}$} & \multicolumn{2}{|l|}{ Validation } & \multicolumn{3}{|c|}{ Quality check: DNA } & \multicolumn{4}{|c|}{ Quality check: RNA } \\
\hline & & & $\begin{array}{l}\text { (\# of } \\
\text { samples) }\end{array}$ & $\begin{array}{l}\text { Age of } \\
\text { Sample } \\
\text { (years) }\end{array}$ & $\begin{array}{l}\text { Total Yield } \\
\text { (ng) }\end{array}$ & $\begin{array}{l}\text { Fragment } \\
\text { size (bp) }\end{array}$ & PCR & $\begin{array}{l}\text { Total Yield } \\
\text { (ng) }\end{array}$ & $\begin{array}{l}\text { Fragment } \\
\text { size (bp) }\end{array}$ & PCR & NanoString \\
\hline $\begin{array}{l}\text { Heikal et } \\
\text { al. }\end{array}$ & $5 \times 5 \mu \mathrm{m}$ & DNA & 12 & $7-22$ & $88-300$ & $103-351$ & $\checkmark$ & & & & \\
\hline $\begin{array}{l}\text { Chung et } \\
\text { al. }\end{array}$ & $1 \times 20$ um & RNA & 9 & $>5$ & & & & $\begin{array}{l}16,000- \\
23,000\end{array}$ & $100-200$ & $\checkmark$ & \\
\hline $\begin{array}{l}\text { Antica et } \\
\text { al. }\end{array}$ & $2 \times 4 \mu \mathrm{m}$ & RNA & 18 & No data & & & & $\begin{array}{l}\text { Unknown } \\
(621 \mathrm{ng} / \mathrm{\mu l})\end{array}$ & $80-202+$ & $\checkmark$ & \\
\hline $\begin{array}{l}\text { Ghatak et } \\
\text { al. }\end{array}$ & $5 \times 5 \mu \mathrm{m}$ & $\begin{array}{l}\text { DNA and } \\
\text { RNA }\end{array}$ & 5 & 1 & 14256 & $<1030$ & $\checkmark$ & 16000 & $109-400+$ & $\checkmark$ & \\
\hline $\begin{array}{l}\text { Hennig et } \\
\text { al. }\end{array}$ & $1 \times 10 \mu \mathrm{m}$ & $\begin{array}{l}\text { DNA and } \\
\text { RNA }\end{array}$ & 210 & $1-25$ & No data & No data & $\checkmark$ & No data & No data & $\checkmark$ & \\
\hline \multicolumn{12}{|c|}{ Laser Capture Microdissection } \\
\hline & \multirow{2}{*}{\begin{tabular}{|l} 
Tissue \\
Input \\
(mm2)
\end{tabular}} & \multirow{2}{*}{$\begin{array}{l}\text { Extracted } \\
\text { Nucleic } \\
\text { Acid }\end{array}$} & \multicolumn{2}{|l|}{ Validation } & \multicolumn{3}{|c|}{ Quality check: DNA } & \multicolumn{4}{|c|}{ Quality check: RNA } \\
\hline & & & $\begin{array}{l}\text { (\# of } \\
\text { samples) }\end{array}$ & $\begin{array}{l}\text { Age of } \\
\text { Sample } \\
\text { (years) }\end{array}$ & $\begin{array}{l}\text { Total Yield } \\
\text { (ng) }\end{array}$ & $\begin{array}{l}\text { Fragment } \\
\text { size (bp) }\end{array}$ & PCR & $\begin{array}{l}\text { Total Yield } \\
\text { (ng) }\end{array}$ & $\begin{array}{l}\text { Fragment } \\
\text { size (bp) }\end{array}$ & PCR & NanoString \\
\hline $\begin{array}{l}\text { Snow et } \\
\text { al. }\end{array}$ & $1-2$ & DNA & 110 & $0-2$ & 430 & No data & $\checkmark$ & & & & \\
\hline
\end{tabular}

Table 1: A comparison of published DNA and RNA extraction protocols for tissue cores, sections and laser capture microdissections. Also included are several molecular endpoints assessment of these methods using PCR and Nanostring assays.

\section{Discussion}

For successful extraction of DNA and RNA from tissue regions of interest, accurate coring is critical. This protocol describes the use of a tissue punch to isolate $0.6 \mathrm{~mm}$ diameter cores and outlines the process for transferring notations from microscope slides to corresponding FFPET blocks. Modifications to the manufacturer's protocol were required to efficiently extract nucleic acids from cores, which are approximately 50 times thicker than the microtome sections for which the protocol was intended. Since the cores may contain more paraffin wax relative to tissue sections, effective deparaffinization of cores through repeated xylene and ethanol treatment steps were required. The success of the postdeparaffinization steps depended on proper mechanical tissue cores homogenization and efficient proteinase K digestion. Further optimization of the proteinase $\mathrm{K}$ digestion can be performed.

It is worth mentioning that this method identifies areas of interest on the surface of the block, as identified in corresponding histopathology slides. As the core harvests tissue that may be 3 or $4 \mathrm{~mm}$ deep, users of this protocol may be concerned about what cells or tissues lay beneath the block surface. While this is a valid concern, multiple studies (reviewed in reference ${ }^{27}$ ) have demonstrated that tissue cores faithfully represent the histologic and molecular features of pathologic tissue blocks, particularly when duplicate or triplicate cores are sampled from the area of interest.

As the modified commercial extraction kit adopted in this protocol enables concurrent extraction of both DNA and RNA from the same tissue, the protocol saves precious biological material and allows a direct comparison between the two resulting nucleic acids from the same sample. Concurrent extraction of RNA and DNA cuts down labor and tissue depletion by half, and enables precise integrated analysis of gene expression, as well as epigenetic and genetic features found in DNA. Since the yields of both RNA and DNA from these representative tissue cores typically exceed 600 and $300 \mathrm{ng}$, respectively, and since most current PCR and next generation sequencing applications typically require 10-100 ng, most of the samples purified by this protocol should provide adequate material for several downstream assays. This protocol has been shown to be reproducible across independent laboratories (Selvarajah et al., In Prep.). RNA from this protocol was of sufficient quality for 
gene expression analysis using either RT-PCR or a popular multianalyte platform, and DNA performed well in methylation specific PCR assays Future studies aimed at assessing the utility of recovered nucleic acids in next generation sequencing are warranted.

Thus, several modifications were made to a commercially available protocol, designed for thin FFPET sections, rendering it suitable for the coextraction of RNA and DNA from $0.6 \mathrm{~mm}$ FFPET cores. The protocol demonstrated consistently high yields in a large cohort of prostate cancer samples and in a limited set of samples from cancers of the breast, brain and bladder. Overall, the protocol should enable users to carry out targeted gene-based analyses of large well-annotated tissue collections. Importantly, the protocol enables efficient focused sampling of regions of interest in FFPET, relatively little hands-on time, and high enough yields for most downstream applications.

\section{Disclosures}

The authors declare no competing financial interests.

\section{Acknowledgements}

This research was supported by a team grant from Movember/Prostate Cancer Canada to JMSB, DMB, PCP, and JL, and by the Ontario Institute of Cancer Research (JMSB, DMB, and PCP) and Motorcycle Ride for Dad Kingston/University Hospitals Kingston Foundation/Kingston General Hospital (DMB, PCP).

\section{References}

1. Kern, S. E. Why your new cancer biomarker may never work: recurrent patterns and remarkable diversity in biomarker failures. Cancer Res. 72 (23), 6097-101 (2012).

2. Klopfleisch, R., Weiss, A. T. A., Gruber, A. D. Excavation of a buried treasure--DNA, mRNA, miRNA and protein analysis in formalin fixed, paraffin embedded tissues. Histol. Histopathol. 26 (6), 797-810 (2011).

3. Beltran, H., et al. Targeted Next-generation Sequencing of Advanced Prostate Cancer Identifies Potential Therapeutic Targets and Disease Heterogeneity. Eur. Urol. 63 (5), 920-926 (2013).

4. Hoppin, J. A., Tolbert, P. E., Taylor, J. A., Schroeder, J. C., Holly, E. A. Potential for selection bias with tumor tissue retrieval in molecular epidemiology studies. Ann. Epidemiol. 12 (1), 1-6 (2002).

5. Ahlfen, S., Missel, A., Bendrat, K., Schlumpberger, M. Determinants of RNA quality from FFPE samples. PLOS ONE. 2 (12), e1261-e1261 (2007).

6. Masuda, N., Ohnishi, T., Kawamoto, S., Monden, M., Okubo, K. Analysis of chemical modification of RNA from formalin-fixed samples and optimization of molecular biology applications for such samples. Nucleic Acids Res. 27 (22), 4436-4443 (1999).

7. Pikor, L. A., Enfield, K. S. S., Cameron, H., Lam, W. L. DNA extraction from paraffin embedded material for genetic and epigenetic analyses. J. Vis. Exp. 26(49) (2011).

8. Turashvili, G., et al. Nucleic acid quantity and quality from paraffin blocks: defining optimal fixation, processing and DNA/RNA extraction techniques. Exp. Mol. Pathol. 92 (1), 33-43 (2012).

9. Espina, V., et al. Laser-capture microdissection. Nat. Protoc. 1 (2), 586-603 (2006).

10. Hackler, L., Jr, Masuda, T., Oliver, V. F., Merbs, S. L., Zack, D. J. Use of laser capture microdissection for analysis of retinal mRNA/miRNA expression and DNA methylation. Methods Mol. Biol. 884, 289-304 (2012).

11. Bonin, S., Stanta, G. Nucleic acid extraction methods from fixed and paraffin-embedded tissues in cancer diagnostics. Expert Rev. Mol. Diagn. 13 (3), 271-282 (2013).

12. Bonin, S., et al. Multicentre validation study of nucleic acids extraction from FFPE tissues. Virchows Archiv. 457 (3), $309-317$ (2010).

13. Montaser-Kouhsari, L., et al. Image-guided Coring for Large-scale Studies in Molecular Pathology. Appl. Immunohistochem. Mol. Morphol. (2015).

14. Eijk, R., Stevens, L., Morreau, H., van Wezel, T. Assessment of a fully automated high-throughput DNA extraction method from formalin-fixed, paraffin-embedded tissue for KRAS, and BRAF somatic mutation analysis. Exp. Mol. Pathol. 94 (1), 121-125 (2013).

15. Ghatak, S., Sanga, Z., Pautu, J. L., Kumar, N. S. Coextraction and PCR Based Analysis of Nucleic Acids From Formalin-Fixed ParaffinEmbedded Specimens. J. Clin. Lab. Anal. (2014).

16. Hennig, G., et al. Automated extraction of DNA and RNA from a single formalin-fixed paraffin-embedded tissue section for analysis of both single-nucleotide polymorphisms and mRNA expression. Clin. Chem. 56 (12), 1845-53 (2010).

17. Snow, A. N., Stence, A. A., Pruessner, J. A., Bossler, A. D., Ma, D. A simple and cost-effective method of DNA extraction from small formalinfixed paraffin-embedded tissue for molecular oncologic testing. BMC Clin. Pathol. 14 (1), 30 (2014).

18. Torrente, M. C., et al. DNA extraction from formalin-fixed laryngeal biopsies: Comparison of techniques. Acta Otolaryngol. 131 (3), $330-333$ (2011).

19. Okello, J. B. A., et al. Comparison of methods in the recovery of nucleic acids from archival formalin-fixed paraffin-embedded autopsy tissues Anal. Bochem. 400 (1), 110-117 (2010).

20. Abramovitz, M., et al. Optimization of RNA extraction from FFPE tissues for expression profiling in the DASL assay. BioTechniques. 44 (3), 417-23 (2008).

21. AllPrep DNA/RNA FFPE Handbook. (2012).

22. Laurent, L. C., et al. Meeting report: discussions and preliminary findings on extracellular RNA measurement methods from laboratories in the NIH Extracellular RNA Communication Consortium. Journal of Extracell. Vesicles. 4, 26533 (2015).

23. Wieczorek, D., Delauriere, L., Schagat, T. Methods of RNA Quality Assessment. Available from https://www.promega.ca/resources/pubhub/ methods-of-rna-quality-assessment/. (2012).

24. Herman, J. G., Graff, J. R., Myohanen, S., Nelkin, B. D., Baylin, S. B. Methylation-specific PCR: a novel PCR assay for methylation status of CpG islands. Proc. Natl. Acad. Sci. U.S.A. 93. (18), 9821-9826 (1996). 
25. Weisenberger, D. J., Campan, M., et al. Analysis of repetitive element DNA methylation by MethyLight. Nucleic acids research. 33 (21), 6823-36 (2005).

26. Yegnasubramanian, S. Hypermethylation of CpG Islands in Primary and Metastatic Human Prostate Cancer. Cancer Res. 64 (6), 1975-1986 (2004).

27. Parsons, M., Grabsch, H. How to make tissue microarrays. Diagn. Histopathol. 15 (3), 142-150 (2009). 